\title{
From outsider to insider: how creative professional service firms internationalise
}

\author{
Author 1 Name: \\ Role: \\ Department: \\ University/Institution: \\ Country:
}

\author{
Author 2 Name: \\ Role: \\ Department: \\ University/Institution: \\ Country:
}

\author{
Author 3 Name: \\ Role: \\ Department: \\ University/Institution: \\ Country:
}

\author{
Dr Deirdre McQuillan \\ Lecturer \\ School of Management \\ University of Bradford \\ United Kingdom
}

Prof. Pamela Sharkey Scott

Professor in International Business

School of Business

Dublin City University

Ireland

\author{
Prof. Vincent Mangematin \\ Professor in Management \\ Kedge Business School \\ France
}

Structured Abstract:

Purpose - The management of reputation and status is central to creative professional service firms (CPSFs) rendering the internationalisation process a particular challenge. We build on arguments that internationalisation requires moving from outsidership to insidership within client networks and focus on how CPSFs build signals about quality to start this process.

Design/methodology/approach - The exploration draws from the international business, professional services and organizational status bodies of literature. A multiple case study design is developed comprising ten Irish architecture firms. In-depth semi-structured interviews were conducted.

Findings - The findings clarify how relationships start in the internationalisation process through signal building. This allows firms to join client networks moving from outsidership to insidership. Our findings systemise three different approaches for CPSFs: from outsidership to insidership within a local market network, within a global industry network and within a global project network.

Research Limitations/Implications - Research within other sectoral and geographical contexts could support transferability of the findings.

Practical implications - The study has implications for CPSF's international business strategies as it identifies multiple paths to gaining network insidership and the tactics employed to achieve this.

Originality/Value - We believe that incorporating signal building mechanisms into the internationalisation process is a novel approach to theorizing about how CPSFs move from outsidership to insidership. We offer important theoretical insights into the international business, professional service firm and organizational status literatures. CPSF business leaders should benefit as it helps them to focus on a portfolio of signal building approaches that can start the internationalisation process. 


\section{From outsider to insider: how creative professional service firms}

\section{internationalise}

\section{Introduction}

Creative professional service firms (CPSFs) including architecture, advertising and fashion design firms (Von Nordenflycht, 2010, Hesmondhalgh, 2002, Throsby, 2001) depend on their reputation to signal the quality of their offering and attract business (Lu et al., 2012, Hitt et al., 2006, Cooper et al., 2000, Rose, 1998). The criteria for assessing broad appreciation and social approval of CPSFs, their activities and outputs tends to be culturally and institutionally embedded in the local markets in which they operate (Faulconbridge and Muzio, 2012, Pratt and Jeffcut, 2009). The challenge for CPSFs therefore is to signal the quality of their activities and outputs when internationalising in new markets.

The rich literature on internationalisation explains how firms move from outsidership to insidership, joining networks through developing relationship ties and escalating resource commitments over time (Schweizer, 2013, Johanson and Vahlne, 2009). Theories of internationalisation emphasise that as trust develops through knowledge sharing, customer centric relationships deepen and grow (Coviello, 2006, Sharma and Erramilli, 2004, Johanson and Matteson, 1988, Oviatt and Mcdougall, 1994). Concurrently, the professional service firm literature insists that reputation is central to building trust about quality when internationalising (Lu et al., 2012, Hitt et al., 2006, Cooper et al., 2000, Rose, 1998). The expert and locally embedded nature of the CPSF service implies that clients need to trust in the quality of their work before a mutual agreement to work together starts a business relationship (Morgan and Quack, 2005, Dwyer et al., 1987, Ford, 1980). Yet, while 
recognising the critical importance of quality signals such as reputation, it is not theorised how firms build such perceptions about quality. We need to understand how CPSFs can signal the quality of their work to allow them to join client networks when moving into new foreign domains.

To address this gap and identify the implications of quality signals for CPSF internationalisation, we ask how do CPSFs move from outsidership to insidership with in international client networks? Using ten architecture firms, we shed light on this problem by undertaking a fine grained analysis of the activities of the firms involved in the creation of signals about quality. Our findings recognise three distinct approaches that CPSFs adopt: moving from outsidership to insidership within a local market network, within a global industry network and within a global project network. Each of the three approaches exhibits a distinct process for building signals of quality involving four dimensions - interpreting the signals of quality required, resourcing for signal building, configuring resources, and transmission including direct signal building activities.

Our findings allow us to contribute to theory in three important ways. First, we extend our understanding of internationalisation processes by uncovering how expert firms such as CPSFs move from outsidership to insidership through signal building about quality for distinct client networks. We systematically classify how CPSFs join an international client network according to the impact of their activities on a local market, global industry and global project network. Our second contribution is to the professional service firm literature revealing how firms build signals about quality when internationalising. We uncover how firms overcome the network constraints of reputation through combining both reputation building and status building activities in the internationalisation process. Last but not least, we offer valuable insights on a hierarchy of networks that firms navigate when 
internationalising for global project business. We show how professional, public representative and client networks often interact to help CPSFs reach international clients.

Our findings provide meaningful insight for managers in CPSFs demonstrating the portfolio of tactics for building signals that can be adopted to target different customers internationally.

Our paper is structured as follows. First, we present our theoretical framing by providing an overview of the literatures relating to moving from outsidership to insidership and signal building. This is followed by details of our research design. We then present and theorise from our findings before discussing our managerial implications.

\section{Literature Review}

\section{Moving from outsidership to insidership in international client networks}

Central to theories of how firms internationalise is the assumption that the 'liability of outsidership' or lack of market specific business knowledge and the absence of trust within client networks is diluted over time (Schweizer, 2013, Johanson and Vahlne, 2009). Emerging insights are now beginning to clarify how firms can overcome this liability of outsidership (Demirbag et al., 2016, Schweizer, 2013, Hilmersson and Jansson, 2012). These explanations emphasise that knowledge of the internationalising firm is transferred incrementally to network actors and that network relationships are based on mutual learning from such knowledge. From this process trust is established.

Insidership starts when a firm has managed to develop one, or a set of, business relationships within a relevant client network (Hilmersson and Jansson, 2012, Johanson and Vahlne, 2009, Blankenburg Holm, 1995). Where expert services are traded however, information asymmetries will inherently exist between what the firm and the client know 
and understand. The work quality of experts such as CPSFs is often opaque to clients (Von Nordenflycht, 2010, Gross and Kieser, 2006, Lowendahl, 2000). For example, a client engaging an architect to design a building is implicitly trusting that the quality of the design and implementation will meet or surpass their aesthetic, functional and commercial requirements even if the client does not understand how this will be achieved. The firm must send appropriate signals about quality to be selected by the client.

But how are such signals about quality transmitted when internationalising? For CPSFs, as generally small operators, this challenge is exacerbated as they move into new institutional and cultural contexts (Faulconbridge and Muzio, 2012, Pratt and Jeffcut, 2009). For example, a firm of architects expanding from the UK to Germany must respond to different customs, work roles and formal institutional requirements when doing business in the foreign location. Notwithstanding, a CPSF even without international client network relationships may be drawn to internationalisation for many reasons such as a unique project opportunity, the desire for celebrity, access to resources, or the opportunity to replace declining business elsewhere (Winch, 2008, Loane and Bell, 2006, Ojala and Tyrväinen, 2006, Sklair, 2006, Chetty and Patterson, 2002, Winch and Schneider, 1993, Mintzberg et al., 1988). CPSFs do not always follow clients into foreign markets, they often seek to internationalise in markets where they are unknown and therefore do not have a reputation.

In the absence of established network relationships, we now understand that internationalising CPSFs must actively move from outsidership to insidership within foreign client networks. But we do not know how this process starts. We need to theorise how CPSFs build signals about quality to join foreign client networks to understand the phenomenon of moving from oustidership to insidership. 


\section{Signal building to start international relationships}

The inherent tension between creative aspirations and the more prosaic aspects of business ensures that CPSFs are generally small firms (Mintzberg et al., 1988, Blau, 1984). They are often operating in niche segments (Winch and Schneider, 1993, Coxe et al., 1988). Some firms follow more creative strategies while others focus more on replicating a portfolio of standard offerings (Winch and Schneider, 1993, Larson, 1993, Coxe et al., 1988). These strategic approaches present distinct challenges for internationalising (Malhotra and Hinings, 2010, Winch, 2008). CPSFs also experience greater challenges compared to other professional service sectors in their need to combine art and professionalism which requires them to often remain small (Winch, 2008, Javalgi et al., 2003). Given these peculiarities, insights from the rich work on the internationalisation of larger professional service firms such as accounting and law firms (see Von Nordenflycht, 2010) which enjoy access to widespread global relationships fails to explain the CPSF internationalisation process.

Work to date recognises that CPSFs rely on both reputation and status to signal the quality of their output in established markets. Here, we define reputation as broad public recognition of the quality of a firm's activities and outputs (Rindova et al., 2005).

Concurrently, status is defined here as the firm's position in a social hierarchy that results from accumulated acts of deference (Sauder et al., 2012). Increasingly recognised as separate, albeit interrelated constructs, reputation and status play differing roles in how firms construct markets (Pollock et al., 2015, Chandler et al., 2013, Jensen and Roy, 2008, Washington and Zajac, 2005, Rindova et al., 2005). While reputation may influence the origin of status in a market, it may also become decoupled from status (Washington and Zajac, 2005). The literature emphasizes examples such as when firms are entering a new 
market or where there is uncertainty about artistic or technical value (Podolny and Stuart, 1995, Podolny, 1994, Lang and Lang, 1988). When CPSFs are internationalising we argue therefore that both status and reputation are critical signals of quality to new clients.

Theory substantiates the centrality of reputation in the internationalisation process (Lu et al., 2012, Hitt et al., 2006, Cooper et al., 2000, Grosse, 2000). Reputation is recognized as a signal of quality yet the literature stops short of explaining how reputation is internationalised. But reputation is network dependent (Lin et al., 2009, Podolny, 1993) and a reputation for quality at a local level does not automatically extend or translate to foreign markets. For example, 'Bettys Tea Rooms' in Yorkshire is perceived in the region as an iconic institution with a reputation for its old style confectionary. Queues are often seen at the door. Yet this reputation does not travel outside of the local region. Conversely, signals of status may traverse across networks (Graffin et al., 2013, Sauder et al., 2012, Simcoe and Waguespack, 2011). For example, organisations that hold a Royal Warrant of Appointment by the British royal family may rely on this as a calling card when entering new markets. This leads us to argue that investigating the combined complexities of how CPSFs build and manage reputation and status signals is central to understanding how they join international client networks.

Theory gives us some guidance on how firms actually build reputation and status signals emerging on a consensus that the process requires not only engaging activities inside the firm but also extending to engagement of outside parties (Zafirau, 2008, Fombrum, 1996). This is required because both reputation and status are external assessments about firms and therefore diverse views can be maintained by different parties (Boutinot et al., 2015, Carter and Deephouse, 1999). CPSFs need to be able to engage and influence their prospective international client networks. In both their internal and external activities, 
internationalising CPSFs must make resource allocations to signal their reliability and predictability to outside observers (Fombrum and Van Riel, 1997, Myers and Majluf, 1984). This suggests a need for these firms to configure their resources to transmit strong signals or to give the international client network a clear understanding of the firm's ability to deliver to the network's requirements.

Signal building for reputation relies on aligning corporate values and firm cultural identity (Goldberg et al., 2003, De Chernatony, 1999, Fombrum and Van Riel, 1997). This demands that organisational members share similar interpretations and have a strong commitment to both firm and shared industry principles (Zafirau, 2008, Goldberg et al., 2003, Fombrum and Van Riel, 1997). Such reputation building also comes from tangible reputation assets in a portfolio of products and services, although firms may also signal the quality of their expertise symbolically (Zafirau, 2008, Jones, 2002). For example, professional awards are a symbolic signal to others about the quality of a product or service.

In contrast to the product approach of reputation building, the foundations of status signalling are sociological and CPSFs must rely on the market observing the traits of the firm (Thye, 2000, Berger et al., 1977). Activities such as exchanging favours, demonstrating generosity and prestige through arranging access to other high status allies and valuable networks enable firms to build status (Sauder and Fine, 2008, Flynn et al., 2006, Thye, 2000 ,). Relationships and connections to institutions of high standing can also help reinforce the perception of a firm's status in international markets (Zafirau, 2008).

In recognition of this gap in our understanding of how CPSFs internationalise, we ask how do these firms signal quality to move from outsidership to insidership in international client networks. The following section details the research setting and design developed to answer this question. 


\section{Methodology}

Investigations into how CPSFs move from outsidership to insidership have largely overlooked the challenges involved in joining international client networks when signals about quality are unknown. In response a qualitative multiple case study research design was developed (Yin, 2009).

\section{Research Setting}

The setting for our study is the architecture industry, specifically internationalising Irish architecture firms. Trading in professionalism and creativity, architecture firms must satisfy both clients and professional peers (Winch and Schneider, 1993, Gutman, 1988). While different categories for CPSFs (cultural, classic, regulated or liberal professions) can exist depending on various definitions of professional services and creative industries, architecture is an industry convincingly situated in the segment of creative professional service firms (Von Nordenflycht, 2010, UNCTAD, 2010, DCMS, 1998, Reed, 1996).

Ireland is particularly appropriate as a research context. Government policy and institutional structures in Ireland have long supported the internationalisation of architecture firms and the small size of the domestic market has provided a catalyst for widespread internationalisation (Enterpriselreland, 1999). Globally, industry internationalisation has been driven by technological advancements, mutual practice agreements facilitating the portability of qualifications and standards, global outsourcing and offshoring. Globalisation trends have also led to developments in architecture such as the 'iconic' architect and buildings that have special symbolic/aesthetic significance attached to them (Sklair, 2005). These buildings, owned by corporates or states have 
created new global opportunities and conditions for architects (Sklair, 2006). Thus while there is evidence of the growing relevance of internationally and even globally successful small CPSFs, the question of how these firms, given their locally embedded characteristics, can internationalise in the first instance remains.

\section{Research Design}

In designing our research method we started by creating a report to assess the viability of the Irish architecture industry as a research setting and identifying its dominant logic (Prahalad and Bettis, 1986). Prepared in 2010, the report identified 178 registered architecture practices in Ireland with 25 promoting international experience that were potential targets for our study. We also undertook some preliminary semi structured interviews to explore how CPSFs internationalise more generally. We interviewed senior architects in three international practices in 2010. We also interviewed one academic from an internationally recognised school of architecture and one senior manager within the building services division of Ireland's government export agency. The interviews and our report later guided us in our case selection, identified any needs to refine our research design and helped to develop the interview prompt sheet around the knowledge gap identified. Our preliminary interviews confirmed that international architecture practices in Ireland varied by size, intensity of international experience, and member definitions as either 'commercial' or 'design' practices which we classified as firm orientation. To ensure firmer grounding for theory development compared with a more homogenous sample (Harris and Sutton, 1986) we incorporated these three variation characteristics into our case selection. 


\section{Data Collection}

Having determined and verified our research design, we embarked on our main stage of data collection. Using introductions from our preliminary stage interviewees we gained access to three case firms (Alpha, Beta and Delta), adding new cases until the point of theoretical saturation (Eisenhardt, 1989). Using multiple techniques, including face-to-face semi-structured interviews, archival data and external informant interviews, our main stage data was collected over four years. The open ended format of interviews allowed us to capture a rich description of how the firms moved from outsidership to insidership when internationalising (Appendix A).

To alleviate potential recall bias, we adopted certain techniques, in particular those relating to historical descriptions including triangulating information from multiple data sources (Huber, 1985, Huber and Power, 1985). Within each case firm we collected data from multiple interviewees at several hierarchical levels in order to mitigate bias (Eisenhardt and Graebner, 2007). We interviewed several external informants to provide the outsider perspective for a reality check, secondary replication and triangulation of findings (Santos and Eisenhardt, 2009, Van De Ven, 2007). The external informants between the preliminary and main stage included developers, academics, government agency and foreign practice representatives. Through rigorous data collection procedures and cross-checking multiple data sources, we ensured rich multi-voice data satisfying the triangulation principle and strengthening the validity of our research findings (Creswell, 2009, Yin, 2009).

The interviews lasted between 40 and 100 minutes, and followed a common protocol. They were all recorded, transcribed and subsequently verified with interviewees before being copied into the NVivo software system. Field notes were written up within 24 hours to reduce any retrospective sense making that might lead to bias (Turner and 
Rindova, 2012, Eisenhardt and Graebner, 2007). Overall, we collected thirty-seven interviews (Table 1 ) between the preliminary (5) and the main stage (32) across ten case firms and nine external informant interviews between the preliminary (2) and the main stage (5).

To safeguard respondents' anonymity and to ensure the confidentiality of our data, we assigned code names based on the Greek alphabet to each case firm, ranging from Alpha to Lambda (Eta excluded), and numbered the interviewees in chronological order.

\section{Insert Table 1 about here}

\section{Data Analysis}

For the sake of simplicity we present the steps in our data analysis sequentially. In reality we conducted multiple data analysis iterations, traveling between our data, the emerging observations and existing literature (Locke, 2001). The firm formed the basic unit of analysis.

Step 1:- Broad Level Coding. Our literature review informed us that signal building involves activities both internal within the CPSF; external to the client network and high status arbiters; together with communication, auditing and alignment of signals. We commenced our data analysis adopting these three broad level codes.

Step 3: Refining of Coding. We then sub-categorised data under our broad level codes to identify patterns and meaning within and across firms. Upon completion of this step we found 939 empirical observations, which we refined and sub-categorised into 47 themes, representing our first order findings.

Step 4: Theoretical Underpinning. We next extracted the theoretically explanatory dimensions from the data and first-order findings, traveling back and forth between our 
data, emerging insights, and existing theory (Eisenhardt, 1989, Gioia and Chittipeddi, 1991). We explored by following thematic analysis the process of how firms move from outsidership to insidership in international client networks. Table 2 presents the structuring of the data. From the 47 first order themes we developed 12 second order theoretical categories which we finally grouped into three aggregate dimensions explaining the three approaches that architecture practices adopt for joining international client networks.

\section{Insert Table 2 about here}

\section{Findings}

Our investigation identified three approaches adopted by CPSFs to join international networks. We explain these approaches as moving from outsidership to insidership within a local (or regional) market network, moving from outsidership to insidership within a global (single) industry network, and last but not least, moving from outsidership to insidership within a global (single) project network. Within each approach our findings detail four dimensions that influence the movement from outsidership to insidership. Firstly, interpreting what signals of quality are required, secondly resourcing for signal building based on the interpretation, thirdly configuring of resources to enact or to communicate signals, and finally signal transmission and direct signal building activities.

\section{From outsidership to insidership within a local market network}

Moving from outsidership to insidership within a local market network as illustrated in Table 3 is evidenced in each of Alpha, Gamma, Delta, Epsilon, Kappa, Zeta, lota and is enacted 
when firms aim to deliver lower cost or more efficient buildings for customers that adhere to international quality standards. This activity involves being visible and close to the customer on the ground in a foreign market.

\section{Insert Table 3 about here}

Interpreting quality requirements from a local market network. Five of our case firms (Alpha, Delta, Gamma, Kappa, Zeta) identified how they build on prior experience gained either domestically or internationally offering superior efficiency in building or other low cost criteria for competing in new markets. A thick homogenous firm culture was particularly evident in Gamma where all informants described how having the implementation team involved at the outset ensured money could be saved by combining designers and technicians throughout the building process. Alpha also exhibited an interpretation of what clients want with Informant \#1 suggesting how "because of their management structure, you would just literally accompany the director to that meeting and sometimes he [the director] might not be there" suggesting how roles were very flexible and became stretched during fast growth periods. This approach is described by Alpha as being on the commercial 'rat run', competing aggressively with others based on a range of multi-specialist architectural services. A similar albeit less dense cultural identity is exhibited by Zeta where an informant details how the 100 year old firm converted from a family partnership to a private company in the 1990's but "the kind of ethos of a family business hung on" (Informant \#1, Zeta).

Resourcing for signalling quality to a local market network. While we could identify a consistency of patterns for resourcing across Alpha, Delta, Gamma, Kappa, Zeta's 
international and domestic activities, we also found that despite differing firm orientations both Epsilon and lota likewise adapted their strategy to engage with local market networks rather than competing for one-off cultural projects. This is possibly due to their recognition that sometimes "philosophy is a luxury in some sense and pragmatism and survival exist" (Epsilon \#5). It also reflects the practical need that the public tendering process favours larger firms for public work and "we need to partner to win that scale of job" (lota \#1). Resourcing to compete internationally for market based work recognises that to join new networks in foreign markets potential clients and other network actors must be able to trust in advance that a firm can design and deliver a local building with superior efficiency for cost savings. To signal the capability to achieve this in a foreign environment requires competency in international sales and marketing and to invest resources on the ground. This includes staff who will travel to manage local resources and to sell the firm's service with Alpha \#3 informing us that "traditionally architects never see themselves as selling as opposed to designing, but [they] are selling all the time.".

Configuring to signal quality to a local market network. Firms replicate their services from their portfolio of expertise delivering the project in an unfamiliar institutional environment. Asymmetries of information are therefore mostly related to localisation considerations with individuals needed for communication on the ground and to build trust about the firm's capability to deliver. Kappa \#5 describes how “we couldn't leave it and say drop over every six weeks. It was immensely important that we had someone on the ground.". Similarly institutional norms may require local agents to act as high status arbiters in forming relationships with clients, such as members of the royal family in the Middle East. It can take a long time for trust to develop within local networks, with Zeta \#1 informing us that "you hear of people doing that [meeting about a project opportunity] and two years 
later they get a phone call out of the blue". Thus joining international client networks requires resources for communicating and visible commitment to project delivery.

Transmitting signals and signal building for local reputation and status. This involves consistency and control of the 'efficiency' message both inside and outside the firm. Key management are transferred to the foreign location to align headquarters and local office culture and identity. Careful consideration and management of local alliances is also important with recognition that "any bad signal from the representative can put a whole project in jeopardy" (Zeta \#3). Indeed some of our firms such as Gamma prefer not to take the risk of working through intermediaries or partners where possible suggesting that "particular difficulties were people pulling the wool over your eyes....[with] local consultants, the fundamental thing they are looking at is the dollar sign" (Gamma \#3). Artefacts such as generating marketing literature in the local language and establishing a portfolio of international credibility are central to this approach of building insidership in a local market network.

\section{From outsidership to insidership within a global industry network}

Moving from outsidership to insidership in a global industry network, as illustrated in Table 4 , is characterised by firms that aim to deliver industrial buildings for highly specialized purposes. This activity requires a deep understanding of industry requirements and the flexibility to work globally in accordance with a global customer strategy.

\section{Insert Table 4 about here}


Interpreting quality requirements from a global industry network. Both Gamma and Epsilon presented with fairly autonomous business segments that focused on specialised industrial architecture projects. Here the individuals involved suggest quite a different interpretation compared to becoming an insider in a local market network or a global project network. Our government agency informant observed that "few practices have an awareness of [industrial architecture] or have a perception of how they can break into this market" (external informant \#1). Certainly, the high technical specialisation of the buildings ensures firms are outsiders from relevant industry networks if they have not gained similar home market experience. These informants identify how they need to blend into the particular industry segment "integrate[ing] the technical side of the project more with the building" (Epsilon \#3) and speaking their language. This identity is distinct from the more traditional professional work with Kappa \#2 informing us that "people who are in that market must know what they are talking about.".

A primary differentiator in the firm's interpretation of quality signals is the willingness of the firm to interact as a more integrated industry specialist rather than as pure architects. This contrasts sharply with other cases who resist industrial architecture with Alpha \#3 suggesting "I am an architect and I like it.".

Resourcing for signalling quality to a global industry network. These firms resource through engaging individuals who will travel to support project implementation across the globe. While Epsilon could replicate its expertise in specialised sports facilities on a global scale, some sectors involving multinational or supranational customers such as pharmaceuticals or ICT demands more focussed responses. Following projects in Ireland, Kappa \#1 informs us that "we had finished a large project for [Pharma co] here [in Ireland] and again we were able to work with them in Europe on a much bigger project". Promoting 
and building engineering capabilities as well as design expertise is also important. Thus signalling to this client network involves having a credible portfolio of expertise and experienced people who can communicate in the language of the industry.

Configuring to signal quality to a global industry network. Accessing global industry networks requires centralised sales and marketing activites to communicate with multinational and global companies and institutions. Meanwhile design production and implementation phases require a hybrid of centralisation and localisation catering to global technical specifications but dealing with local institutions and bureaucracy. Client trust gained from past projects demonstrates specialised experience. Notably industrial clients understand design aspects better than clients of more traditional forms of architecture. In Kappa and Epsilon dedicated individuals are assigned to market and sell industrial design and implementation services to multinational or supranational industry customers. Emphasising the importance of particular industry expertise Kappa \#2 advises that “I can't just put any architect out there, they don't know what I am doing so how can they defend my land". This ensures that specialised industrial architecture remains a distinctive business unit within both Epsilon and Kappa.

Transmitting signals and signal building for industry specific reputation and status. A portfolio of specialised projects is important as a signal of quality for industrial clients within their industry. These customers have a superior ability to understand quality and needs compared to other private or public customers. Moreover, past customers are likely to be known in industry circles inferring status benefits by association, in particular for our case firms Epsilon and Kappa, word of mouth is important and Epsilon gives an example of this whereby the president of a sports body is effectively acting as an introducer on their behalf for other overseas clubs. As our firms expand into other industry segments however, more 
proactive signalling activities are required such as creating high quality marketing literature and website development. Cold calling activities by specific individuals within Kappa and Epsilon play a role, particularly when moving into different industries to promote capabilities developed from experience. Industrial architecture requires a certain amount of independence from the rest of the firm, highly selective recruitment processes and tightly controlled contact points for joining a global industry network.

\section{From outsidership to insidership within a global project network}

Moving from outsidership to insidership within a global project network as illustrated in Table 5 is characterized by firms that target work or projects based on the artistic component and the uniqueness of design.

\section{Insert Table 5 about here}

Interpreting quality requirements from a global project network. Five of our firms Beta, Epsilon, lota, Lambda, Theta were passionate about their design work and Beta, Epsilon, Lambda and Theta sought access to global project networks when internationalising. Employees spoke of their work as involving "a deep belief in architecture, and the value of architecture first and foremost" (Beta \#1). This view was shared not only by the original founders but across their teams, with Theta \#2 referring to "the idea of the office" and the commitment required to achieve these ideals "because it is so labour intensive. It must survive on the idea being fed by hard work and I have never come across a bunch of people who have worked so hard.". This alludes to the alignment of values and 
culture in this case firm. Behind this passion is a common belief in the cultural value of architecture and the "need to understand the culture, you have to be more than just an architect" (Epsilon \#4). Interpreting international business in this way pushes firms to create unique buildings, where "they don't really believe in specialisations" (Lambda \#3). Yet their design processes allow for ideas to be reconfigured and combined across the team to "provide design solutions to a clearly defined problem in a cultural context" (Theta \#3). Maintaining this approach demands rigid recruitment processes. Additionally firms are usually organised into a studio structure of architects rather than technicians. There is a broad consensus across many informants including the principals that "I am not an administrator. I am an architect. I have no interest [in non-architecture related business issues]." (Lambda \#1).

Resourcing for signalling quality to a global project network. Resourcing for internationalisation from a culturally embedded interpreting approach logically follows the path that firms "select projects rather than markets" (Beta \#1) or "We don't select anything. We get selected by people." (Lambda \#1). As noted already however, moving from a domestic to an international client network is challenging with both Epsilon and lota signalling to join more local market networks internationally rather than targeting global projects, even though they are recognised as good quality design firms. This to some extent creates a tension between their shared beliefs and interpreting how to signal quality. For Beta, Theta and Lambda who strongly align their interpreting both domestically and internationally, practical adaptations become helpful such as building foreign language capabilities. More importantly however, there is recognition that internationalising through global project networks requires enormous resources to engage in high profile competitions as "we might do 200 competitions and only 2 of them turn into jobs" (Theta \#4). Thus using 
research resources from universities supports investment in design capabilities and technology by these firms enabling successful international outcomes. Gamma the most organised for local market networks simply acquires 'an old sage' to compete for cultural projects sometimes required as an internationally recognised signal.

Configuring to signal quality to a global project network. Signalling for this approach is based on CPSF design capabilities which are centrally organised. The emphasis is on "delivering buildings of a high standard and we hope then that they will speak for themselves" (Theta \#4). Firms often eschew any discussion about marketing or sales activities beyond possibly pointing to their website. Thus while these firms are often joining a new international client network for each project, linkages to other non-client networks are very important for signalling the quality of their offering. They also create alliances with high status global consultants. Professional network linkages are key for interpreting quality as they are fellow experts and can act as arbiters in international client networks. Similarly links to government representatives and arts councils are important because they also have geographic reach and status. Strong educational links are important too for transmitting global signals. In the design firms "up to two thirds of architects in the office teach as well" (Beta \#3). Links to more prestige establishments are created as professional reputation grows. Educational links similarly provide the research resources needed for competition success and the opportunity to find the best students and imprint on the profession.

Transmitting signals and signal building for global reputation and status. Signalling activities revolve around highly selective engagement with professional and public representative networks requiring good access from key principals. The informants from design firms say they do not cold call, suggesting "I wouldn't know how to do it. [Cofounder] is not like that either" (Lambda \#1). It is interesting to note that rather than trying 
to form new client relations, signals are created by outsiders such as awards from professional networks, media activity generated from public representative networks or by national or international arts councils. In this regard the firm's portfolio of buildings signal the firm's quality of service which is in turn confirmed by experts and high status arbiters. A lot of activity therefore is focused on peer, public representative, educational and arts based relationship building, thus engaging experts and high status individuals to interpret and create reputation and status for the firm to become known in a global project network.

\section{Discussion}

Despite the importance of internationalisation for service firms, there is still a major gap in our understanding of how small expert firms in the arts and in professions overcome the liability of outsidership. We need to understand how such firms start relationships when perceptions about quality need to be established in advance. In response, our approach to investigating how CPSFs move from outside to inside international client networks allows us to advance theory in three ways. First, we extend our understanding of internationalisation processes for CPSFs by uncovering how these firms move from outsidership to insidership through signal building about quality to distinct client networks. Second, we reveal how firms overcome the network constraints of reputation through combining both reputation building and status building activities in the internationalisation process. Third, we reveal valuable insights on a hierarchy of networks that firms navigate when internationalising for global project business.

\section{From outsider to insider in an international client network}


Responding to the need to understand how CPSFs join international client networks, our first contribution is to the internationalisation process literature. Contemporary literature theorising firm internationalisation converges on the importance of networks of relationships (Johanson and Vahlne, 2009, Oviatt and McDougall, 1994,), in particular for smaller, non-internet platformed firms (Krull et al., 2012, Coviello, 2006, Sharma and Erramilli, 2004). Theories of internationalisation identify mutual knowledge sharing and information gathering as the means by how firms join foreign networks (Krull et al., 2012, Hilmersson and Jansson, 2012, Johanson and Vahlne, 2009). This explanation assumes that relationships exist and can simply be deepened, but this leaves the question of how CPSFs can join international client networks. We reveal that for CPSFs the process of building signals to start relationships in international client networks constitutes a critical phase in explaining how CPSF internationalisation happens.

Our findings substantiate that internationalisation requires signals about quality in advance of starting a relationship. Yet current literature does not explain how firms build these signals. We add to our understanding of how firms overcome the liability of outsidership by demonstrating that building signals about quality requires four dimensions involving interpreting what signals are required, resourcing for signal building, configuring of resources, and transmission which also includes the building of signals directly. By classifying the signalling process according to the type of client network targeted, we offer a theory for how CPSFs move from outsidership to insidership when internationalising.

\section{How reputation is internationalised}

Our second contribution enriches theories of professional service firms. Many scholars in this field agree on the central importance of reputation in the internationalisation process 
(Lu et al., 2012, Hitt et al., 2006, Cooper et al., 2000, Rose, 1998). There is also widespread acceptance that reputation is bounded by networks (Lin et al., 2009, Podolny, 1993). The question of how reputation is internationalised however is not explored. The professional service firm literature, which is dominated by studies of large firms in more scalable industries such as accounting and law firms (Von Nordenflycht, 2010), does not recognise that internationalising firms may be unknown in new markets and therefore need to build signals about quality. For CPSFs, to be recognised for quality of activities and outputs in one market does not ensure a reputation in a new market. Our work shows how CPSFs build signals about quality to join new networks.

Our exploration of how small professional service firms such as CPSFs overcome the constraints of reputation boundaries provides new insight into the internationalisation process. Our findings address calls for better insight into the challenges of internationalisation for small professional service firms typical of CPSFs. We also contribute to the need for more fine grained insight into service sector internationalisation more generally, responding to the need for complementary analysis into the process to account for special characteristics (Villar et al., 2012).

A distinction between status and reputation is recognised in studies (Chandler et al., 2013, Washington and Zajac, 2005,). The literature also clarifies that reputation and status are particularly distinguishable in situations of high uncertainty such as internationalisation (Simcoe and Waguespack, 2011, Washington and Zajac, 2005). We add to our understanding of both concepts by detailing how in the absence of a reputation, status acts as a signal of quality for internationalising CPSFs. By revealing how firms build and align perceptions about their service quality to different networks we demonstrate how, perhaps counterintuitively, resource constrained CPSFs must choose between putting resources into 
controlling quality through direct local market interfacing activities or putting resources into design and allowing other high status experts to interpret quality signals from their work.

\section{Hierarchies of networks for gaining global project network insidership}

Our findings confirm the role of status building activities to start international client network relationships and offer interesting insights into how status is built across network hierarchies. We demonstrate a more complex hierarchy of networks at play in CPSF internationalisation for global project work. This helps to close knowledge gaps in the organisational status literature (Sauder et al., 2012, Washington and Zajac, 2005). Prior explanations show how firms move from open to gradually closing networks (Hilmersson and Jansson, 2012), or emphasise only the international client network in the internationalisation process (Schweizer, 2013). Our explanation shows how CPSFs move from outsidership to insidership within a global project network. The results provide insights into how multiple networks can support entry into a specific client network for CPSFs through an interplay of different activities. In this instance a client network could exist anywhere across the globe but it is often temporary in nature, usually confined to a single project. Our findings demonstrate how CPSFs utilise supranational networks (Demirbag et al., 2016) in the form of professional and public representative networks, where different rules of the game exist in order to signal to remote unknown clients. Our study has implications for further work to address the relationship between network hierarchies and moving from outsidership to insidership in client networks.

\section{Managerial implications}


CPSFs usually remain local because of the challenges of becoming known in foreign markets. The aspect of 'becoming known' in the internationalisation process is fundamental to successfully crossing borders, yet it is largely overlooked in the literature. Although many managers may be aware of the extent of their reputation, they may be less familiar with how they can build quality signals. Our study provides a number of valuable insights by explaining how CPSFs become known outside of their immediate networks at home and abroad.

By identifying three routes to move from outsidership to insidership in international (market, industry and project) client networks CPSFs can envisage their internationalisation process as a choice about selecting appropriate clients and creating signals for their network. CPSFs may gain business abroad by entering a direct client network in a local market or in a specific industry, but we also show how managers can internationalise in a more circuitous way by manoeuvring though multiple expert and public representative networks to build the necessary signals about quality. Our study therefore provides managers with a portfolio of tactics for starting relationships.

We further assist managers by revealing the complexity of building signals about quality which is necessary for CPSF internationalisation into markets where prior relationships do not exist. We show how this can be both created and aligned within and outside the firm through interpreting, resourcing, configuring and transmitting/signal building activities. In explaining this we offer a firmer understanding of the effort, activities and resources required throughout the firm as opposed to merely decisions and organising at the customer interface.

Finally, we identify the interplay and hierarchy of different networks for CPSFs targeting global project customers. Understanding the role and importance of each network 
as a means to win business provides managers with key tactics on how and where to focus resources and efforts.

\section{Limitations and further research}

Although caveats may apply to our qualitative multiple case study research for conceptual generalisation of our theorising, we expect that our findings will have potential for transferability to other CPSF sectors or other broader professional service sectors with similar characteristics. We also note that the ideas emerging from our findings may be transferable to other more traditional service sectors, given the value of research designs involving unusual contexts (Schofield, 2000).

Another limitation to note is the relative underrepresentation of data relating to moving from outsidership to insidership within a global industry network. Across our ten firms, only two firms were involved in industrial architecture but they did exhibit a distinctive approach for joining international client networks adding a valuable aspect to our findings. Future studies could explore and compare more fully this segment of the architecture industry servicing specialised industrial projects.

We also point out that we do not explore the issue of choice in this study. Our aim was to theorize about how firms move from outsidership to insidership in international client networks. Further studies to explain why firms choose a particular approach to internationalise could add value to our study. 
RUNNING HEAD: From Outsider to Insider

\section{Conclusion}

Our study identifies three approaches to starting relationships that enable CPSFs to move from outsidership to insidership within international client networks. Arguing that joining international client networks is influenced by multiple dimensions of interpreting, resourcing, configuring and building signals about quality addresses an important gap in our understanding of how CPSFs internationalise. In sum, this study advances our understanding of how CPSFs, often small firms, can compete for international opportunities. 


\section{References}

Berger, J., Fisek, M., Norman, R. and Zelditch, M. (1977) Status Characteristics and Social Interaction. Elsevier, New York.

Blankenburg Holm, D. (1995) 'A network approach to foreign market entry', in: Moeller, K. and Wilson, D. (ed.) Business Marketing: an interaction and network perspective. Blower: Kluwer Academic Publishers, pp. 375-405.

Blau, J. (1984) Architects and Firms: a sociological perspective on architectural practice. Cambridge, MIT Press, Mass.

Boutinot, A., Ansari, S., Belkhouja, M. and Mangematin, V. (2015) 'Reputational spillovers: evidence from French architecture', Strategic Organisation, 13(4), pp. 284-306.

Carter, S. and Deephouse, D. (1999) 'Tough talk' and 'soothing speech': managing reputations for being tough and for being good', Corporate Reputation Review, 2(4), pp. 308-332.

Chandler, D., Huanschild, P., Rhee, M. and Beckman, C. (2013) 'The effects of firm reputation and status on internorganisational network structure', Strategic Organisation, 11(3), pp. 217-244.

Chetty, S. and Patterson, K. (2002) 'Developing internationalisation capability through industry groups: the experience of a telecdommunications joint action group', Journal of Strategic Marketing, 10(1), pp. 69-89.

Cooper, D., Rose, T., Greenwood, R. and Hinings, B. (2000) 'History and contingency in international accounting firms', in: Aharoni, Y. and Nachum, L. (ed.) Globalisation of services: some implications for theory and practice. Routledge, London.

Coviello, N. (2006) 'The network dynamics of international new ventures', Journal of International Business Studies, 37(5), pp. 713-731.

Coxe, W., Hartung, N., Hochburg, H., Lewis, B., Maister, D. and Mattox, R. (1988) Success strategies for design professionals. John Wiley, New York.

Creswell, J. (2009) Research design: qualitative, quantitative and mixed methods approaches. Sage, Thousand Oaks, CA.

Department of Culture, Media and Sport (DCMS) (1998) 'Creative Britain: new talents for the new economy', [Online]. Available at: http:/www.culture.gov.uk/images/publications/CEPFeb2008.pdf (Accessed: 01 May 2017)

De Chernatony, L. (1999) 'Brand management through narrowing the gap between brand identity and brand reputation', Journal of Marketing Management, 15, pp. 157-179.

Demirbag, M., Mcguinness, M., Akin, A. and Bayyurt, N. (2016) 'The professional service firm in a globalised economy: a study of the efficiency of securities firms in an emerging market', International Business Review, 25, pp. 1089-1102.

Dwyer, R., Schurr, P. and Oh, S. (1987) 'Developing Buyer-Seller Relations', Journal of Marketing 51(2), pp. 11-27.

Eisenhardt, K. (1989) 'Building theories from case study research', Academy of Management Review, 14(4), pp. 532-550.

Eisenhardt, K. and Graebner, M. (2007) 'Theory building from cases: opportunities and challenges', Academy of Management Journal, 50(1), pp. 25-32.

Enterprise Ireland (1999) 'Opportunities in design: strategies for growth in the Irish design sector', [Online]. Available at: http://www.garrettstokes.com/wp-content/uploads/2010/04/Opportunitiesin-Design-Report-1999-Enterprise-Ireland.pdf (Accessed: 01 May 2017)

Faulconbridge, J. and Muzio, D. (2012) 'Professions in a globalising world: towards a transnational sociology of the professions', International Sociology, 27(1), pp. 109-125.

Flynn, J., Reagans, R., Amanatullah, D. and Ames, D. (2006) 'Helping one's way to the top: self monitors achieve status by helping others and knowing who helps whom', Journal of Personality and Social Psychology, 91(6), pp. 1123-1137. 
Fombrum, C. (1996) Reputation: realising value from corporate image. Harvard Business School Press, Boston.

Fombrum, C. and Van Riel, C. (1997) 'The reputational landscape', Corporate Reputation Review, 1(1/2), pp. 5-15.

Ford, D. (1980) 'The development of buyer-seller relationships in industrial markets', European Journal of Marketing, 14(5/6), pp. 339-354.

Gioia, D. and Chittipeddi (1991) 'Interpreting and sensegiving in strategy change initiation', Strategic Management Journal, 12(6), pp. 433-448.

Goldberg, A., Cohen, G. and Fiegenbaum, A. (2003) 'Reputation building: small business strategies for successful venture development', Journal of Small Business Management, 41(2), pp. 168-186. Graffin, S., Bundy, J., Porac, J., Wade, J. and Quinn, D. (2013) 'Falls from grace and the hazards of high status: negative returns to status among British MPs; the 2009 expense scandal and its impact on parliamentary elites', Administrative Science Quarterly, 58(3), pp. 313-345.

Gross, C. and Kieser, A. (2006) 'Are consultants moving towards professionalisation?', Research in the Sociology of Organisations: Professional Service Firms, 24, pp. 69-100.

Grosse, R. (2000) 'Knowledge creation and transfer in global service firms', in: Aharoni, Y. and Gutman, R. (1988) Architectural practice: a critical review. Princeton Architectural Press, New York. Harris, R. and Sutton, R. (1986) 'Functions of parting ceremonies in dying organisations', Academy of Management Journal, 29, pp. 5-30.

Hesmondhalgh, D. (2002) The Cultural Industries. Sage Publications, London.

Hilmersson, M. and Jansson, H. (2012) 'International network extension processes to institutionally different markets: entry nodes and processes in exporting SMEs', International Business Review, 21, pp. 682-693.

Hitt, M., Bierman, L., Uhlenbruch, K. and Shimizu, K. (2006) 'The importance of resources in the internationalisation of professional service firms: the good, the bad and the ugly', Academy of Management Journal, 49(6), pp. 1137-1157.

Huber, G. (1985) 'Temporal stability and response-order biases in participant descriptions of organisational decisions', Academy of Management Journals, 28, pp. 943-950.

Huber, G. and Power, D. (1985) 'Retrospective reports of strategic-level managers: guidelines for increasing their accuracy', Strategic Management Journal, 6, pp. 171-180.

Javalgi, R., Griffith, D. and White, S. (2003) 'An empirical examination of factors influencing the internationalisation of service firms', Journal of Services Marketing, 17(2), pp. 185-201.

Jensen, M. and Roy, A. (2008) 'Staging exchange partner choices: when do status and reputation matter?', Academy of Management Journal, 51(3), pp. 495-516.

Johanson, J. and Matteson, L. (1988) 'Internationalisation in industrial systems; a network approach', in: Hood, N. and Valne, J. (ed.) Strategies in Global Competition. Croom Helm, London.

Johanson, J. and Vahlne, J. (2009) 'The Uppsala internationalisation process model revisited: from liability of foreignness to liability of outsidership', Journal of International Business Studies, 40, pp. 1141-1431.

Jones, C. (2002) 'Signaling expertise: how signals shape careers in creative industries', in: Peiperl, M., Arthur, M. and Anand, N. (ed.) Career Creativity: Explorations in the Remaking of Work. Oxford University Press, Oxford, pp. 209-228.

Krull, A., Smith, and P.Ge, G. (2012) 'The internationalisation of engineering consulting from a strategy tripod perspective', The Service Industries Journal, 32(7), pp. 1097-1119.

Lang, G. and Lang, K. (1988) 'Reputation and renown: the survival of artistic reputation', American Journal of Sociology, 94, pp. 79-109.

Lin, Z., Yang, H. and Arya, B. (2009) 'Alliance partners and firm performance resource complementarity and status association', Strategic Management Journal, 30, pp. 921-940.

Loane, S. and Bell, J. (2006) 'Rapid internationalisation among entrepreneurial firms in Australia, Canada, Ireland and New Zealand: an extension to the network approach', International Marketing Review, 23(5), pp. 467-485. 
Locke, K. (2001) Grounded theory in management research. Sage, Thousand Oaks, CA.

Lowendahl, B. (2000) 'Strategic management in professional service firms', Copenhagen Business School Press, Copenhagen.

Lu, V., Quester, P., Medlin, C. and Scholz, B. (2012) 'Determinants of export success in professional business services: a qualitative study', The Services Industries Journal, 32(10), pp. 1637-1652.

Mintzberg, H., Otis, S., Shamsie, J. and Waters, J. (1988) 'Strategy of design: a study of architects in co-partnership', in: Grant, J. (ed.) Strategic Management Frontiers. JAI Press, Greenwich.

Morgan, G. and Quack, S. (2005) 'Institutional legacies and firm dynamics: the growth and internationalisation of UK and German law firms', Organisation Studies, 26(12), pp. 1765-1785. Myers, S. and Majluf, N. (1984) 'Corporate financing and investment decisions when firms have information investors do not', Journal of Financial Economics, 13, pp. 187-221

Ojala, A. and Tyrväinen, P. (2006) 'Business models and market entry mode choice of small software firms', Journal of International Entrepreneurship, 4(2-3), pp. 69-81.

Oviatt, B. and McDougall, P. (1994) 'Toward a theory of international new ventures', Journal of International Business Studies, 25(1), pp. 45-64.

Podolny, J. (1993) 'A status based model of market competition', American Journal of Sociology, 98(4), pp. 829-872.

Podolny, J. (1994) 'Market uncertainty and the social character of economic exchange',

Administrative Science Quarterly, 39, pp. 458-483.

Podolny, J. and Stuart, T. (1995) 'A Role Based Ecology of Technological Change', American Journal of Sociology, 100(5), pp. 1224-1260.

Pollock, T., Lee, P., Jin, K. and Lashley, K. (2015) '(Un)Tangled', Administrative Science Quarterly, 60(3), pp. 482-517.

Prahalad, C. and Bettis, R. (1986) 'The dominant logic: a new linkage between diversity and performance', Strategic Management Journal, 7(6), pp. 485-501.

Pratt, A. and Jeffcut, P. (2009) Creativity, Innovation and the Cultural Economy. Routledge, London. Reed, M. (1996) 'Expert power and control in late modernity: an empirical review and theoretical synthesis', Organisation Studies, 17, pp. 573-598.

Rindova, V., Williamson, I., Petkova, A. and Sever, J. (2005) 'Being good or being known: an empirical examination of the dimensions, antecedents and consequences of organisational reputation', Academy of Management Review, 31(1), pp. 51-71.

Rose, T. (1998) Coordination and Integration Processes in Global Business Advisory Firms: The Role of Global Clients, University of Alberta, Edmonton.

Santos, F. and Eisenhardt, K. (2009) 'Constructing markets and shaping boundaries: entrepreneurial power in nascent fields', Academy of Management Journal, 52(4), pp. 643-671.

Sauder, M. and Fine, G. (2008) 'Arbiters, entrepreneurs, and the shaping of business school reputations', Sociological Forum, 23(4), pp. 699-722.

Sauder, M., Lynn, F. and Podolny, J. (2012) 'Status: insights from organisational sociology', Annual Review of Sociology, 38, pp. 267-283.

Schofield, J. (2000) 'Increasing the generalisability of qualitative research', in: Gomm, R., Hammersley, M. and Foster, P. (ed.) Case Study Method. Sage Publications, London.

Schweizer, R. (2013) 'SMEs and networks: overcoming the liability of outsidership', Journal of International Entrepreneurship, 11, pp. 80-103.

Sharma, V. and Erramilli, M. (2004) 'Resource-based explanation of entry mode choice', Journal of Marketing Theory \& Practice, Winter, pp. 1-15.

Simcoe, T. and Waguespack, D. (2011) 'Status, quality, and attention: what's in a (missing) name?', Management Science, 57(2), pp. 274-290.

Sklair, L. (2005) 'The transnational capitalist class and contemporary Architecture in globalising cities', International Journal of Urban and Regional Research, 29(3), pp. 485-500.

Sklair, L. (2006) 'Iconic architecture and capitalist globalisation', City, 10(1), pp. 22-47.

Throsby, D. (2001) Economics and culture. Cambridge University Press, Cambridge 
Thye, S. (2000) 'A status value theory of power in exchange relations', American Sociological Review, 65(3), pp. 407-432.

Turner, S. and Rindova, V. (2012) 'A balancing act: how organisations pursue consistency in routine functioning in the face of ongoing change', Organisation Science, 23(1), pp. 24-46.

United Nations (UNCTAD) (2010) 'Creative Economy Report', [Online]. Available at:

http://unctad.org/en/Docs/ditctab20103_en.pdf (Accessed: 01 May 2017)

Van De Ven, A. (2007) Engaged scholarship: a guide for organisational and social research. Oxford University Press, Oxford.

Villar, C., Pla-Barber, J. and Leon-Darder, F. (2012) 'Service characteristics as moderators of the entry mode choice: empirical evidence in the hotel industry', The Service Industries Journal, 32(7), pp.

1137-1148.

Von Nordenflycht, A. (2010) 'What is a professional service firm? towards a theory and taxonomy of knowledge intensive firms', Academy of Management Review, 35(1), pp. 155-174.

Washington, M. and Zajac, E. (2005) 'Status evolution and competition: theory and practice', Academy of Management Journal, 48(2), pp. 282-296.

Winch, G. (2008) 'Internationalisation strategies in business to business services: the case of architectural practice', The Service Industries Journal, 28(1), pp. 1-13.

Winch, G. and Schneider, E. (1993) 'Managing the knowledge-based organisation: the case of architectural practice', Journal of Management Studies, 30(6), pp. 923-937.

Yin, R. (2009) Case study research: design and methods. Sage Publications Inc, Thousand Oaks, CA. Zafirau, S. (2008) 'Reputation work in selling film and television: life in the hollywood talent industry', Qualitative Sociology, 31, pp. 99-127. 


\section{Appendix A: Interview Prompt Sheet}

Please begin by describing your business.

How would you describe your role within your organisation?

How do the activities of your department fit within the organisation?

What has been your organisation's experience of internationalising its activities?

What triggered the internationalisation activities?

Where did you internationalise?

How did you identify particular countries to target?

How would you explain the internationalisation process?

Were there are particular successes that you experienced?

Were there are particular difficulties that you experienced?

What would you identify as the key complexities within the process? How did you address these?

How did you establish relationships in your target country?

Who are your important relationships for internationalising?

How did you develop the new structure?

How did you transfer creativity?

How did you manage knowledge?

How did you approach building a reputation in the host country?

How would you describe your organisation's general approach? 
Table 1. Description of data collected from each case firm and sampling criteria

\begin{tabular}{|c|c|c|c|c|c|c|c|c|}
\hline \multirow[b]{2}{*}{$\begin{array}{l}\text { Name (No of } \\
\text { Informants) }\end{array}$} & \multirow[b]{2}{*}{$\begin{array}{c}\text { Est. } \\
\text { (years)+ }\end{array}$} & \multirow[b]{2}{*}{ Recognized Sector Expertise } & \multicolumn{3}{|c|}{ Size Variability } & \multicolumn{2}{|c|}{ International Experience Variability } & \multirow{2}{*}{$\begin{array}{c}\begin{array}{c}\text { Firm Orientation } \\
\text { Variability }\end{array} \\
\text { Peer Identification }\end{array}$} \\
\hline & & & $\begin{array}{l}\text { Empl. Nos. } \\
\text { (largest over } \\
\text { decade)+ }\end{array}$ & No. of Offices & $\begin{array}{l}\text { Selected Projects } \\
\text { listed on website }\end{array}$ & $\begin{array}{c}\text { Years since first } \\
\text { international } \\
\text { experience+ }\end{array}$ & $\begin{array}{l}\text { No. of international } \\
\text { projects (regions) }\end{array}$ & \\
\hline Alpha (5) & 30 & Multi Specialist - Commercial & $50(250)$ & 6 & 75 & 15 & $\begin{array}{c}10 \\
\text { (AM; CEE;MENA;WE) }\end{array}$ & Commercial \\
\hline Beta (3) & 30 & Specialist - Education & 20 & 1 & 18 & 10 & $\begin{array}{c}7 \\
\text { (AM; WE) }\end{array}$ & Design \\
\hline Gamma (3) & 25 & Multi Specialist - Commercial & $100(300)$ & 4 & 154 & 15 & $\begin{array}{c}32 \\
(A A ; A M ; C E E ; M E N A ; \\
\text { WE) }\end{array}$ & Commercial \\
\hline Delta (2) & 25 & $\begin{array}{l}\text { Dual Specialist - Retail / Project } \\
\text { Management }\end{array}$ & $25(85)$ & 1 & 18 & 15 & $\begin{array}{c}4 \\
\text { (MENA; WE) }\end{array}$ & Commercial \\
\hline Epsilon (5) & $\begin{array}{c}30^{*} \\
\text { (now } 5)\end{array}$ & $\begin{array}{l}\text { Multi Specialist - Public \& } \\
\text { Commercial }\end{array}$ & $20(250)$ & $1(6)$ & $\begin{array}{l}49 \text { (assigned to } \\
\text { existing } \\
\text { directors) }\end{array}$ & 25 & $\begin{array}{c}27 \\
(A A ; A M ; C E E ; M E N A ; \\
\text { WE) }\end{array}$ & Design \\
\hline Kappa (5) & 100 & $\begin{array}{l}\text { Multi Specialist - Public \& } \\
\text { Industrial }\end{array}$ & $100(200)$ & 7 & 86 & 35 & $\begin{array}{c}18 \\
\text { (AA; CEE; MENA; WE) }\end{array}$ & Commercial \\
\hline Zeta (3) & 100 & Multi Specialist - Commercial & $50(100)$ & 3 & 99 & 35 & $\begin{array}{c}14 \\
\text { (AA; CEE; MENA; WE) }\end{array}$ & Commercial \\
\hline Theta (4) & 15 & Specialist - Cultural & 20 & 1 & 23 & 10 & $\begin{array}{c}11 \\
(\mathrm{AA} ; \mathrm{AM} ; \mathrm{MENA} ; \mathrm{WE})\end{array}$ & Design \\
\hline lota (3) & 15 & Specialist - Education & 20 & 1 & 40 & 10 & $\begin{array}{c}4 \\
\text { (MENA; WE) }\end{array}$ & Design \\
\hline Lambda (4) & 35 & $\begin{array}{l}\text { Dual Specialist -residential and } \\
\text { cultural }\end{array}$ & 15 & 1 & 39 & 15 & $\begin{array}{c}7 \\
(\mathrm{AM} ; \mathrm{WE})\end{array}$ & Design \\
\hline
\end{tabular}

$*_{\text {in }} 2010$ Epsilon went into liquidation and the partners formed a new partnership, employing former architects and working in a co-operative arrangement with other former architects of the firm.

+ Years established and Years since first international experience, employee numbers and years since first international experience are rounded to the nearest five.

$\sim$ Number of international projects identified between company website and informant interviews was 134 in total across 45 countries. Synthesized into geographic region here comprising 42 in Western

Europe (WE), 31 in Middle East/North Africa (MENA), 29 in Central and Eastern Europe (CEE), 21 in other Asian countries (AA) and 11 in the Americas (AM). 
RUNNING HEAD: From Outsider to Insider 
Table 2: Data Structure

\begin{tabular}{|ll}
\hline Empirical evidence (first order) & Theoretical categories (second order) \\
\hline $\begin{array}{l}\text { Efficiency of project. } \\
\text { Distinct technician and project management } \\
\text { roles. }\end{array}$ & \\
$\begin{array}{l}\text { Emphasis on firm growth. } \\
\text { Flexible recruitment policies. }\end{array}$ & $\begin{array}{l}\text { Interpreting quality requirements from a local } \\
\text { ISO and other global quality compliance } \\
\text { standards. }\end{array}$ \\
\hline $\begin{array}{l}\text { International sales and marketing resources and } \\
\text { skills. }\end{array}$ & \\
$\begin{array}{l}\text { Local resources for visibility and institutional } \\
\text { needs. }\end{array}$ & \\
$\begin{array}{l}\text { Managers willing to work internationally. } \\
\text { International partnering selection and }\end{array}$ & $\begin{array}{l}\text { Resourcing for signalling quality to a local market } \\
\text { network. }\end{array}$ \\
\hline
\end{tabular}

International partnering selection and network.

identification competencies.

From outsidership to insidership within a local market network

Separation of design towards global centres of expertise and/or centres of low cost drawing. Local(ised) marketing and sales activities. Local implementation stages.

Linkages with high status local introducers or

Configuring to signal quality to a local market international developers. network

Developing local language marketing literature. Portfolio of buildings of international credibility. High status local alliances.

Positioning HQ managers in local offices.

Transmitting signals and signal building for local reputation and status.

Specialization of project.

Dedicated customer contact points.

Emphasis on expertize in building type.

Identifying with customer industry rather than

Interpreting quality requirements from a global

architecture profession.

Industry specific design skills.

People to travel globally on project basis.

Competence in speaking industry language.

Building engineering capabilities.

Resourcing for signalling quality to a global industry network.

rom outsidership to insidership within a global industry network

Centralized sales centred configuration.

Strong links to global specialised industry

Configuring to signal quality to a global industry

Working locally on production on project basis. network.

Portfolio of specialized buildings.

Introductions from industry contacts.

Creating word of mouth path.

Transmitting signals and signal building for

industry specific reputation and status.

Uniqueness of project.

All architects in firm.

Shared belief in cultural value of architecture.

Interpreting quality requirements from a global

project network.

Skills at interpreting design brief.

Ideas management space and capabilities.

Access to research resources.

No' prima donnas' on team.

Resourcing for signalling quality to a global project network.

Foreign language capabilities.

Centralized production centred configuration.

Strong links to professional and arts networks.

High status consultant linkages.

network.

From outsidership to insidership within a global project network

Strong links to education.

Transmitting signals and signal building for global reputation and status

Buildings speak for themselves to experts.

Awards.

High selectivity in professional activities and

projects.

Building CV and easy access to founding

partners. 


\begin{tabular}{|c|c|}
\hline \multicolumn{2}{|c|}{$\begin{array}{c}\text { Table } 3 \\
\text { Illustrative evidence: From outsidership to insidership within a local market network }\end{array}$} \\
\hline $\begin{array}{l}\text { Theoretical } \\
\text { categories }\end{array}$ & Illustrative Quotations \\
\hline $\begin{array}{l}\text { Interpreting quality } \\
\text { requirements from a local } \\
\text { market network. }\end{array}$ & $\begin{array}{l}\text { "For most of our clients we still promote ourselves as a design aware commercial practice" } \\
\text { (Gamma \#2) } \\
\text { "I am an architect. [colleague A] and [colleague B] are two others. They are both project } \\
\text { managers. I think the balance allows us to be almost a one stop shop whenever we do get } \\
\text { business in" (Delta \#1) } \\
\text { "We have a rotation of the managing director role within the company" (Zeta \#3) }\end{array}$ \\
\hline $\begin{array}{l}\text { Resourcing for signalling } \\
\text { quality to a local market } \\
\text { network. }\end{array}$ & $\begin{array}{l}\text { "that market it was all about personal contact, about meeting people. It takes a long } \\
\text { time" (Zeta \#2) } \\
\text { "we've selected people who are prepared to travel." (Kappa \#1) } \\
\text { "we are involved overseas with this [international industry alliance], we are part of a } \\
\text { bigger group. That is a way of building the profile and lets us stand out a bit more" (Iota } \\
\# 3 \text { ) }\end{array}$ \\
\hline $\begin{array}{l}\text { Configuring to signal quality } \\
\text { to a local market network. }\end{array}$ & $\begin{array}{l}\text { "we are there for the long haul, and the firm has to completely change now to allow us to } \\
\text { do that." (Kappa \#4) } \\
\text { "We would be very active going into those markets, finding out, talking to people, finding } \\
\text { out what's going on, following up." (Gamma \#1) } \\
\text { "You tend to be looking all the time at families that are very well connected you know, to } \\
\text { royalty and so on." (Zeta \#1) }\end{array}$ \\
\hline $\begin{array}{l}\text { Transmitting signals and } \\
\text { signal building for local } \\
\text { reputation and status. }\end{array}$ & $\begin{array}{l}\text { "I am getting on top of getting say marketing material fully translated so it is professional." } \\
\text { (Epsilon \#2) } \\
\text { "you need a portfolio that has credibility internationally. So if you show about } 20 \text { projects } \\
\text { in Ireland, they go 'So What?'. So we need to show projects from other parts of the world } \\
\text { to have credibility." (Gamma \#1) } \\
\text { "somebody from here was going out to head up because we needed to have the culture of } \\
\text { the organisation here, to establish that culture over there and then we would train up } \\
\text { individuals over there at local rates if we could find them." (Delta \#2) }\end{array}$ \\
\hline
\end{tabular}

\begin{tabular}{|c|c|}
\hline \multicolumn{2}{|c|}{ Illustrative evidence: From outsidership to insidership within a global industry network } \\
\hline Case Firm & Illustrative Quotations \\
\hline $\begin{array}{l}\text { Interpreting quality } \\
\text { requirements from a global } \\
\text { industry network. }\end{array}$ & $\begin{array}{l}\text { "If you put someone in front of a pharmacist, and the pharmacist starts talking about, I } \\
\text { need a BCR and you will have to deal with it, [another] guy wouldn't have a clue. (Kappa } \\
\# 2 \text { ) } \\
\text { "the development officer for a [specialised sports] club in [AM] was told about it by a } \\
\text { friend of his and thought it would be great if he got [us] to design a new [specialised sports } \\
\text { facility]." (Epsilon \#4). }\end{array}$ \\
\hline $\begin{array}{l}\text { Resourcing for signalling } \\
\text { quality to a global industry } \\
\text { network. }\end{array}$ & $\begin{array}{l}\text { "I have already employed an engineer here that speaks Flemish and Dutch and French } \\
\text { here, which helps" (Kappa \#2) } \\
\text { "physical distance. I think it probably will pay off if you put in the hard slog" (Epsilon \#4) }\end{array}$ \\
\hline $\begin{array}{l}\text { Configuring to signal quality } \\
\text { to a global industry } \\
\text { network. }\end{array}$ & $\begin{array}{l}\text { "at World Bank you need to have a local" (Kappa \#2) } \\
\text { "You need to explain aspects like we needed to meet them there to convince them the } \\
\text { curved roof was important." (Epsilon \#3) }\end{array}$ \\
\hline $\begin{array}{l}\text { Transmitting signals and } \\
\text { signal building for industry } \\
\text { specific reputation and } \\
\text { status. }\end{array}$ & $\begin{array}{l}\text { "we are doing a good job for one company, they talk to another company" (Kappa \#1) } \\
\text { "We are hoping to expand on that again and apparently they have been checking us out as } \\
\text { far away as [AA]. (Epsilon \#3) }\end{array}$ \\
\hline
\end{tabular}




\begin{tabular}{|ll|}
\hline \multicolumn{1}{|c|}{ Illustrative evidence: From outsidership to insidership within a global project network } \\
\hline \multicolumn{1}{|c|}{ Case Firm } & \multicolumn{1}{c|}{ Illustrative Quotations } \\
\hline $\begin{array}{l}\text { Interpreting quality } \\
\text { requirements from a global } \\
\text { project network. }\end{array}$ & $\begin{array}{l}\text { "I suppose if you put it on the spectrum of value, the pressure for ourselves is that projects } \\
\text { "I had never interviewed with somebody before who had gone back to the start and said } \\
\text { show me what you did in your thesis. They were trying to match ideologies" (Theta \#2) } \\
\text { "my idea is the concept of architecture having a social dimension" (Epsilon \#4) }\end{array}$ \\
\hline $\begin{array}{l}\text { Resourcing for signalling } \\
\text { quality to a global project } \\
\text { network. }\end{array}$ & $\begin{array}{l}\text { "If you have an idea or a problem you kind of just discuss it with the people around you. } \\
\text { "we use student research as well." (Beta \#1) } \\
\text { "they make those calls and the rest of us make up the difference by just hitting the } \\
\text { deadlines" (Theta \#2) }\end{array}$ \\
\hline $\begin{array}{l}\text { Configuring to signal quality } \\
\text { to a global project network. }\end{array}$ & $\begin{array}{l}\text { "is about working with partners that deliver the kind of standard we are looking for and } \\
\text { also that they want to work with you" (Theta \#4) }\end{array}$ \\
$\begin{array}{l}\text { from Europe to America. They know the top people." (Beta \#2) } \\
\text { "We run what we would call a studio and everyone mucks in with everybody else. We all } \\
\text { work together." (Lambda \#1) }\end{array}$ \\
$\begin{array}{l}\text { Transmitting signals and } \\
\text { signal building for global } \\
\text { reputation and status }\end{array}$ & $\begin{array}{l}\text { "They [the principals] are very hands on from beginning to finish. So from that point of } \\
\text { view the creativity is controlled and consistent." (Theta \#1) } \\
\text { "Probably [Beta's] reputation is going up and up since [building awarded major global } \\
\text { architecture prize]" (Beta \#2) } \\
\text { "We don't select anything. We get selected by people." (Lambda \#1) }\end{array}$ \\
\hline
\end{tabular}

